\title{
Fashion as practice, fashion as process: using principles of language as a framework for understanding the design process
}

\section{Kurennaya, Anya}

\section{Abstract:}

How do creative impulses and lived realities interact and inform one another throughout the design process? This project examines the mechanics of the creative process by observing the work of three graduate fashion design students as a first step toward understanding the nature of the design process and the symbiosis between object and process, using ideas borrowed from modern linguistic theory as the starting point for investigation. Referencing Cholachatpino's et al. (2002) categorization of the microsubjective order of the fashion process as "a dynamic process and not a linear continuum", along with Ingold and Hallam's (2009) notion of cultural

\section{Cuadernos del Centro de Estudios de Diseño y Comunicación Nº 64}

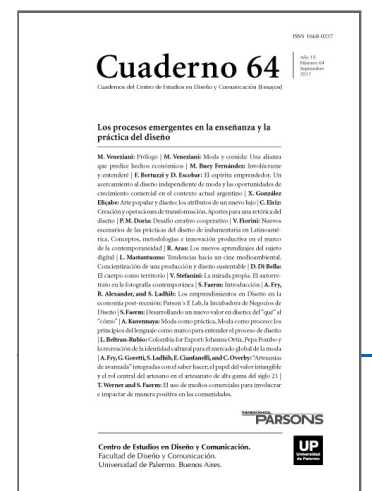

ISSN: 1668-0227

Los procesos

emergentes en la

enseñanza y la

práctica del diseño

Año XVIII, Septiembre 2017, Buenos

Aires, Argentina | 326 páginas

descargar PDF

ver índice de la publicación

Ver todos los libros de la publicación

compartir en Facebook

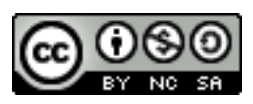

Esta obra está bajo una Licencia Creative Commons Atribución-NoComercialCompartirlgual 4.0 Internacional

improvisation and related theories from the field of linguistic anthropology, this paper argues that the fashion design process is open to the kind of improvisation inherent in any ongoing lived experience, the final product representing a culmination of the ideas, desires, decisions, obstacles, and other circumstances shaping its production. Ideas are not translated into their material form in a fluid and uncomplicated manner; in fact, there are many intervening forms of disruption, diversion, reformulation, and rearticulation, not unlike our everyday use of language in conversation. Reconsidering the design process with an eye toward explaining its collective, nonlinear, and experimental nature allows us to recognize that design has the potential to inform us about society and give us the tools to actively change it.

Key words:

creativity - cultural improvisation - design process - fashion design - language. 
$\left(^{*}\right)$ MA in Fashion Studies from Parsons School of Design. Serves as part-time lecturer in the department of Art and Design History and Theory at Parsons, where she teaches and researches the relationships between fashion and music, beauty and celebrity culture, and fashion and language. She has developed curricula and taught courses centered on zine culture, hip hop culture and style, and social and cultural perspectives on hair.

Any object we use and any garment we wear will have, at some point or another, been actively thought about and designed for use; these steps towards creation may have been taken by a professional designer, a craftsman, or even by us in the role of creator. Inherent in any given object is an underlying idea and a process that brought that idea into reality, into a tangible form. How precisely are these thoughts and ideas translated into a final product?

Do the ideas get transmitted wholesale, or do they undergo revision through the process? And, more importantly, how do creative impulses and lived realities interact and inform one another throughout the design process? How does the designer attempt to control the process, and how does the process, in turn, affect the designer? This project seeks to examine the various mechanics of the creative process by interviewing and observing the work of three different fashion design students as the first step toward understanding the nature of the design process and the symbiosis between object and process. Cholachatpino et al. (2002a, 2002b) have already proposed that the micro-subjective order of the fashion process - that is, the individual's process of adopting, wearing, and moving on from trends- would be better considered as "a dynamic process and not a linear continuum" (2002a, p. 21). I aim to extend these findings to the practice of actual garment design and construction, arguing that the design process is open to the kind of improvisation and diversity inherent in any ongoing lived experience, the final product in this case representing a culmination of the numerous ideas, desires, decisions, pathways, obstacles, and other circumstances shaping its production. That is to say, ideas are rarely translated into their material form from start to finish in a fluid and uncomplicated manner, without any intervening forms of disruption, diversion, reformulation, or rearticulation. Thinking otherwise has led to the development of the myth of the romantic artist (or, in this case, designer), the idea that objects are made in isolation by a sole creator with the gift of rare creative talents and abilities, gifts which very few other members of society possess (Becker 2008, p. 14). This is a particularly Western viewpoint originating at the time of the Italian Renaissance, and it is a belief that does not pertain to the majority of societies (Becker, 2008, p. 15). Furthermore, the consequence of such a myth is the notion that such privileged objects, stemming from the unique mind of the uniquely gifted individual, bear little relation to society in general, or at least to the strata of society not well-versed in the history and culture of art, design, and its makers. This project takes as its starting point the notion that such a construct needs to be reconsidered, particularly in the West where it is most likely to impact the popular understanding of design and its production. Reconsidering the design process with an eye toward explaining its collective, nonlinear, and experimental nature allows us to recognize that design has the potential to inform us about society and give us the tools to actively change it.

\section{Fashion as process and practice: issues and methodologies}

In thinking about the design process and reexamining its boundaries, it is helpful to borrow some ideas from the field of linguistics and, in particular, to trace the development of thinking in fields such as conversation analysis and linguistic anthropology, which developed out of the need to examine language in its social and cultural context, as it actually occurs. Whereas from the 1960s linguists such as Chomsky, who emphasized the study of language through a strict theoretical lens, considered "spontaneous communication as being in some way 
defective" (Liddicoat, 2007, p. 2), researchers in these newly developing fields sought to understand language "as a normal everyday activity" (Liddicoat, 2007, p. 1), to understand it as one of the ways humans interact with one another and shape society.

These fields were to a degree influenced by the sociological tradition of ethnomethodology developed by Harold Garfinkel, which studies "the common sense resources, practices and procedures through which members of a society produce and recognize mutually intelligible objects, events and courses of action" (Liddicoat, 2007, p. 2). Garfinkel was particularly interested in understanding the "common social knowledge" that develops among members of groups and in using this knowledge to explain "how the structures of everyday activities are ordinarily and routinely produced and maintained" (Garfinkel qtd. in Liddicoat, 2007, p. 2). This approach is also useful in that it gives prominence to the participants themselves and the way they assign meaning to their social practices. Working in a process which Garfinkel calls "the documentary method", social actors collect information through their experiences and encounters and then attempt to organize and categorize these facts into a set of patterns, using these patterns as a framework for understanding and organizing their future experiences (Liddicoat, 2007, p. 3). Thus this approach highlights the way individuals construct frameworks for making sense of the world, but this does not suggest that the world, or social order, is necessarily orderly. On the contrary, ethnomethodology is an approach that, while examining the way society is ordered, acknowledges the possibility that social order is "in reality potentially chaotic" (Liddicoat, 2007, p. 2), owing to its context-dependent, organically developed nature. Thus social order is not pre-existing but, rather, is actively developed by members of society, and social order is neither fixed nor unchanging; it is in a constant state of development and flux. Others like Erving Goffman stated the importance of studying these phenomena in the context of everyday experiences and interactions, arguing that "matters of great social significance could be found in everyday activities" (Liddicoat, 2007, p. 3). Those working in the field of linguistic anthropology use these principles to study "ordinary" language activities, generally conducting these studies in a particular field and making use of extended periods of participant-observation (Salzmann, 1998, p. 4). They place importance on the social use of language, the way its speakers use it to communicate their ideas and define their culture (Salzmann 1998, p. 16). Proponents of conversation analysis also use ideas from ethnomethodology to study the patterns and logics that emerge out of spontaneous speech; these patterns lead to the construction of known scripts or schemas (we can think of them as conventions) that speakers use to negotiate their interactions on a daily basis. Speakers are aware of and constantly use these schemas, both to construct their own utterances and to respond to and understand the constructions of others. Schemas and other principles dictate to speakers such things as when they can speak and when they should listen and thus allow the mutual understanding necessary for productive conversation to take place (Ono \& Thompson, 1995). Though these schemas arise, this does not preclude the possibility of deviation or departure from these norms. Rather, these learned schemas serve as organizing principles for talk but can be retooled or repurposed to serve the specific needs of the conversation at hand, i.e. the context in which the conversation takes place. It should also be noted that, because these scripts are produced through practice, they are particular to their temporal and spatial origin and thus vary greatly cross-culturally. Moving from one community to another requires adjusting and reworking existing scripts and learning new ones. Additionally, and perhaps most importantly for our purposes, spontaneous conversation is marked by a large number of pauses, stops, reformulations, retractions, and the like. As anyone who has ever tried to transcribe all or part of a conversation knows, spontaneous discourse is not at all reflective of the controlled, succinct nature of formal speech. On the contrary, producing spontaneous speech is a process that is far from linear and far from controlled, and speakers rely on the input of others to help formulate and advance their utterances, i.e., the overwhelming majority of 
utterances are co-constructed and therefore reliant on collective action and collaboration. This leads us to the related idea of cultural improvisation, discussed by Ingold and Hallam (2009), which involves the following four components. First, it is generative, in the sense that it gives rise to the phenomenal forms of culture as experienced by those who live by them or in accord with them. Second, it is relational, in that it is continually attuned and responsive to the performance of others. Third, it is temporal, meaning that it cannot be collapsed into an instant, or even a series of instants, but embodies a certain duration. Finally, improvisation is the way we work, not only in the ordinary conduct of our everyday lives, but also in our studied reflections on these lives in fields of art, literature, and science. (Ingold \& Hallam 2009, p. 1) Cultural improvisation, as Ingold and Hallam (2009) tell us, is an ongoing process that requires dedication and practice in everyday life. When we read this in conjunction with the principles guiding conversation analysis and linguistic anthropology, we can see that spontaneous speech is a form of cultural improvisation and that speakers must constantly define and redefine language as they go along in everyday practice. Put another way, the collective and spontaneous nature of speech shapes the very definition of what language is; language is not a heavenly gift sent from above but rather the amalgamation of a lot of intensive work, both to produce new ways of speaking but also to maintain those which have come before. This work is collectively performed by a great number of speakers, but it takes place most often between two members of a society engaged in one-on-one conversation; thus language is both individual and collective, introspective and external, both creating and maintaining culture. Looking at all these ideas together, we see a very similar process taking place in fashion. This project, guided by the principle of explaining or demystifying design, is dependent on ethnographic fieldwork which allows us to examine the design process as it actually occurs. In this case, the ethnographic sample consists of three fashion design students, studying in the Fashion Design and Society MFA program at Parsons The New School for Design (since renamed Parsons School of Design, part of The New School). This program presents an ideal venue from which to select a sample owing to its focus on the process of design research and thinking about design's potential for social change. The fieldwork itself consists of individual interviews and sessions of participant-observation in the workroom with each designer. The three students come from different international and educational backgrounds, so their insights prove particularly helpful in examining individual variations in the design process. The students clearly engage with one another to share their thoughts on the design process, but more interestingly, they also engage with their garments in a relational, interactive way: one informs the other and the two become united by the shared goal of expressing an idea. They locate design ideas both within themselves and within other people, places, and things. They seek to innovate through their work but they also seek to uphold and preserve what came before. And the entire process is marked by pauses, interruptions, and reformulations which do not decrease its importance but rather signify its spontaneous and dynamic character. These students become articulate in their area of expertise through a process of learning and experimentation which is rarely straightforward, orderly, or linear in nature.

\section{Education and the collective nature of design}

Of course, unlike language, design is a skill that not everyone is required to learn. Those that choose to pursue fashion design as a career path generally do so in an institutional setting, where they expect to formalize their methods of research, training, and presentation. This is not to say that the practice of design cannot be performed outside of the institutional setting, but the distinction culturally maintained between the two is similar to the distinction between formal and informal speech. Design students undergo education to further practice the skills, refine the concepts, and learn the schemas that will earn them success in the industry. Thus, just as 
dialects mark a person as having grown up in one region or another, the design school plays a role in shaping a student's approach toward and understanding of design. All three students agreed that their undergraduate experience in particular helped shape their approach toward the process of design. One student, who completed her undergraduate BFA at the Fashion Institute of Technology, explained the school's research process as very commercially based; the starting point for a new design was generally a color or a fabric. This MFA program, on the other hand, asks students to conceptualize their ideas in broader terms, looking to sources outside the typical milieu of fashion inspirations. The student I spoke to could attest to the different institutional teaching styles and work cultures, at least between the two particular programs. The existence of these different cultures of working necessitates a shift in the thought process and a period of self-examination and experimentation in order to arrive at a new understanding of what a designer is and does. Thus the institution has the potential to shape or reframe the student's identity as a designer, something Angela McRobbie (1998) describes as the creation of the "fashion subject" (p. 40). This is a "subjectivizing process" by which the designer is ostensibly "built" (McRobbie, 1998, p. 40), learning to channel personal ideas and creativity with the institutional working process, and McRobbie (1998) argues that these "forms of knowledge and experience and these process of shaping up the talent are what produce the final product and thus establish and confirm the reputation of the department" (p. 41). Thus, for McRobbie, this "prescribed subjectivity" serves to "provide a grid" for what a fashion designer is; this can be likened to the previously discussed schemas and scripts, which must be learned and relearned with shifting contexts. Students inevitably learn to modify and adjust their approach at the suggestion of their instructors, but they also sometimes make the decision to retain certain aspects of their working and designing styles as a way to maintain their previously learned identities as designers. One student, drawing on her prior experience working with design instructors, gave an illustrative example of this push-and-pull dynamic:

Sometimes they will suggest things which will appall you and you don't know what to do, because you don't know whether to stick with your guns, or do you think, well these people have thirty years of experience. And it's really, really hard... and a lot of the times they would suggest things which I hated but I would do, because I was too scared to not because, then again, they know what they're talking about. Also because you do trust them ... and a lot of the times the things did pan out for the better... But there were other people in the class who would do things and say, "I don't even know why this piece is here. It's just their [the instructor's] idea". So yeah, you do have to be really strong... you definitely need to think "Is this me?" In fact, all three students spoke about this tension between individuality and conformity in their design work. However, another student mentioned that, although the instructors challenge the students and question them on their design decisions, they also expect the students to argue back and respond to that criticism, so the process is not necessarily oppressive but rather a pedagogical technique revolving around the benefits of critique for strengthening a student's design ethic. Given the range of international backgrounds and vastly dissimilar practices of designing, this MFA program in particular seems especially capable of moving beyond these kinds of institutional constraints and allowing designers to develop a personal voice, one that is not merely personal but also capable of responding to interpersonal and societal issues. Thus the subjectivizing process cannot be equated with a process of homogenization, just as all speakers of a given language do not express their thoughts and ideas in exactly the same way.

\section{Examining the research process}

As mentioned, the Fashion Design and Society MFA program emphasizes a researchbased approach that asks students to look beyond typical fashion sources for their design ideas. For one design brief dealing with the topic of personal identity, each design student was asked to develop an idea or concept of personal interest and 
translate those ideas into a small collection. These ideas could be drawn from all aspects of society, and they did not necessarily have to refer to forms of dress or forms related to the body; according to the course description, possible areas of engagement included literature, film, art, politics, photography, science, anthropology, history, and economics (Parsons, 2010). This exercise asks students to think beyond the conventions of design and to instead question and reflect on them. Each student drew on her experiences and interests to develop ideas of personal significance. One student, hailing from Norway, chose as the starting point of her collection to focus on the light summer dress worn over layers of fur by the Inuit in the wintertime; the dress signifies a feeling of yearning for the hoped-for and imagined feeling of summertime. Though the student referred to items of dress, her research was directed more toward the feelings associated with the dress rather than the visual composition of the dress itself. This approach goes beyond the level of surface structure in an effort to more fully explore the underlying feelings that give rise to the material object, delving into the semantics of the dress itself rather than examining its physical details. In latching on to this feeling rather than the details of the thing itself, the student also keys into a very important notion that Keane and others describe as "semiotic ideology," or the common shared understanding of what a sign is, what it refers to, and how it functions in the world (Keane, 2003, p. 419). Keane (2003) argues that in order to understand the way language (and design) "configure the borders and the possibilities of subjects," one needs "a semiotic analysis of the social power of things [which] would thus demand an account of the semiotic ideologies and their discursive regimentation that enter into or are excluded from the processes by which things become objects" (p. 423). Applying this to the case of the design student, we see she is seeking to engage with the underlying feelings, or semiotic underpinnings, of the dress rather than its surface representation, thereby taking the first step towards questioning what makes an object an object. This is illustrated in her design, which is "based" on the concept of the dress but which does not include the physical form of the dress in any literal or even iconic way. She is delving deep into the semiotic territory of the dress in order to communicate those feelings, and she is doing so by reconfiguring them in a completely different way through her designs. This is quite similar to the concept of translation from one language to another, where the translator must work hard to ignore the surface grammatical structure of each language, seeing instead to take the raw semantic material that is the source of meaning from the original utterance and to reconfigure it using a completely different grammar. Theoretically the two dresses have affinities on the semiotic level, but they are separate in terms of their visual composition. This research idea demonstrates the possibility of communicating feelings through garments in a way that is at once global, in the sense that it is able to reach and resonate with a larger audience due to its reconfiguration of a given idea and dissemination of that idea in multiple objects, but also quite local, depending on the design aesthetic and skill of the particular designer who happens to be undertaking the project (and we might imagine that the same feeling would have wildly different physical manifestations if the task were performed by other designers). Insights into another design student's research process demonstrates the nonlinearity of the design process, as well as the importance of experimentation and improvisation in design. The designer began by coming up with some key words that she felt connected to personally. She spent some time ruminating on their meanings and significance in her own life, trying to look at all the interrelated aspects of the words. She also looked outward to her friends and family for their perspective on the concepts, thus adding a decidedly collaborative and collective element to her research process: "This is what we've been taught, to ask a few people even, what they think about this idea. We were taught that we have to go outside of [ourselves]." The first key word she came up with was "nostalgia," based on her own interest in looking back and reflecting on her past experiences and using those experiences to "encourage [the] future process." Her consultation with her instructor led her to visualize a timeline between the past and the future based off of this concept of nostalgia, where the future was a blank, as yet unfilled by time and action but open to the possibilities. 
Thinking about the future in this way led her to her next keyword, "emptiness", which she conceptualized as similar to "nothingness, but totally different, because emptiness brings all kinds of possibility and leaves the viewer to really define what it is rather than the designer saying, this is what this is about." In her mind, emptiness suggested a simplicity and functionality that was not void of meaning but rather perfectly suited to the user and his needs. Additionally, she asked her friends and family for their perspective on "emptiness," and was particularly moved by her father's characterization of emptiness as "two points". All of these related thoughts led her to question the idea of what makes a thing a thing, what the true essence of something like a garment really is. Working with this culmination of related ideas, she first started to visualize the concept by taking a garment and cutting it into pieces and then putting these pieces back together, taking pictures throughout the process. While she thought this was an interesting exercise to carry out, the result reminded her too much of similar experiments with deconstruction and reconstruction by other designers, so she dropped the idea. Next she was inspired by a picture she saw of an expansive landscape with a miniscule human figure, and this prompted her to take pictures of garments and try to recreate this human landscape. Again the product seemed to prove unsuccessful, so she took on a third experiment, which consisted of taking photos of a shirt on a mannequin from a variety of perspectives: eye-level, bird's eye view, and from the bottom up (see Fig. 1). This approach was the one she found especially intriguing and the one she chose to take further. These resulting visualizations were, for the student, related to the concept of emptiness, and as a way of expressing this, she redid the experiment using a black dress and used photo editing software to digitally combine the three views into one visual "garment," which then became the prototype for her design, the image she was trying to recreate (see Fig. 2). We shall return to the process of construction in a moment, but we should bear in mind that this example demonstrates perfectly a number of interesting trajectories happening throughout the research process. First of all, we see a distinctly interpersonal element, evidenced by the designer's desire to ask others for their impression of the keywords. This is indicative of the social, collective component of the design process, which asks design students to look beyond themselves for ideas and inspiration. We also see nonlinearity and experimentation throughout the process; this dispels the notion that an idea must be fully formed and shaped in the mind of the designer and only needs to be constructed by able hands to come to fruition as an object; rather, the idea has the potential to morph and transform with time, and it relies on external input as well as internal reflection. Again, we can draw a parallel between this process and the process of articulating a thought using language: rarely do we speak in fully formed sentences typical of flowing prose, but rather our speech is marked by a number of reformulations, pauses, and new ideas as it is in the process of being spoken. The design process, in this particular instance, exemplifies the organic and dynamic nature of research and design thinking, and it also demonstrates the way these reformulations and reflections help shape the future direction of the concept, an example of lived reality influencing imagined reality and vice versa. We have seen that, for the interviewed students in this MFA program, larger concepts or ideas thus provide the raw material for the idea of the garment, but the student must be well versed in the techniques of research and garment construction in order to effectively transmit the idea in mind, a topic to which we shall now turn.

\section{Design execution and improvisation}

Lest we subscribe to the notion that the execution of design is a simple matter that relies on the conceptualization or sketch as the direct blueprint for the physical garment, we need simply to turn to observation of garment construction in the workroom to understand that this is rarely if ever the case: the large amount of improvisation 
and revision that occurs during this stage of the design process constitute solid disconfirming evidence of this fact.

First of all, the spontaneous nature of design work became evident when I spoke to a student working on multiple pieces at the same time. She told me that this method of working made sense to her, and observing the freedom with which she moved from one task to another demonstrated her extreme fluency in the skill of design work. However, this does not mean the student did not also struggle with parts of the process. She showed me a complicated sleeve that she had been working on, explaining that she had made at least ten or twelve sleeves before she was able to create the exact shape she had in mind. She felt proud of the final product and was glad she persevered and was finally able to execute her vision, but there was an undoubtedly large amount of effort behind that single sleeve. This is similar to the multiple reformulations that speakers often make when speaking spontaneously, but it is also similar to the kind of editing process that writers of more formal speech engage with. Either way, the intensive work and numerous prototypes indicate a dedication to developing design skills and working to bring an idea to fruition. Another student I observed was creating a garment for a brief presented by a prominent design team working in New York. The designers asked the students to create a garment which used only three total seams and which did not make use of conventional seams found on typical garments, side seams for example. The students were to use anatomical sketches of human musculature and use the lines they found beautiful as the basis for their patterns. The student I was observing had already created a prototype of the garment, which was already on the mannequin, but she was finding herself dissatisfied with the way it was looking and consequently was returning to the pattern pieces to try to discern the problem. I watched her move back and forth between the "actual" garment on the mannequin and her pattern pieces, attempting to discern where they lined up and what needed to be changed in order to fix the visual incongruities manifested in the prototype. This task was further complicated by the fact that it was difficult to discern whether the problem was inaccurate measurements in the pattern pieces or less-than-perfect technical execution during the sewing process. Observing this back-and-forth brought to mind the saliency of the object and the way it seemed to have taken on a life of its own. In theory the pattern and the prototype should have been identical, but the practices and processes involved in the transposition from one to the other somehow introduced new elements into the equation. Looking back to the metaphor of language, this is akin to the production of spontaneous discourse, which in theory should perfectly mirror the speaker's prior conceptualization. In reality, however, the process is locally managed and is open to influence and change due to a number of external factors. Here, the hard mechanical facts of sewing had the ability to derail the final product from its blueprint, as did the misreading of measurements and miscutting of fabric pieces. One might suppose that this student found the entire procedure problematic and frustrating, but she told me she did not find it so; rather, she felt it was important to spend the extra time refining and reformulating the pattern so that the final garment could come closer to her idealization of it. Thus we see here the dynamic and spontaneous nature of the construction process, and we also see the complicated interaction between the object and its maker. For the third student, the one who was attempting to create garments that combined multiple visual perspectives, her workroom procedure involved experimenting and creating a number of "failed" garments before settling on a garment that seemed to visually "work." The first attempt was an experiment which tried simply to recreate the digitally combined dress we saw earlier (see Figures 2-3). The student used a sheer fabric to mimic the transparency inherent in the digitally created layers, and her intention was to display the garment's three different views through the use of the visible seams created when using such a sheer fabric (in looking at the waist, for example, one can discern three seams that correspond to each layer or view of the garment). This was also the rationale for using three different colors of 
sheer fabric. However, after consulting with her instructor, she realized that the idea didn't translate clearly enough. She was advised to visually push the idea farther by connecting the three garments at the waist rather than layering them on top of one another (see Figure 4). This was one of the garments that finally seemed to "work". Similar processes of experimentation surrounded the making of the other garments that constitute the small collection. This process and the final garments both have clear ties to the four aspects of cultural improvisation as discussed by Ingold and Hallam (2009). First, the process was clearly generative, giving rise to a collection of final garments based on original keywords and concepts. Second, it was relational, since its inception was dependent on the input of the student, her instructor, and her friends and family. Third, it was temporal, an ongoing process that consisted of both research and practice and which took a fairly lengthy period of time to conceptualize and execute. Finally, it was a reflection on the way the student works, created through ordinary processes and practices of thinking and making on the part of the design student. Interestingly, when I observed her at work in the studio, she told me that she hoped that this process, and the program more generally, would give her the opportunity to speak through her designs. Talking and explaining, she felt, was not always the best way to present a design; for her personally, she hoped that her designs would be powerful enough to speak for themselves.

\section{Conclusion: fashion design + society}

As we have seen, the students in my sample used design as a way to express thoughts and ideas about society, and their process was intensive, ongoing, and dependent on a high level of persistence and commitment. The findings, examined as they are at level of the individual designing in an institutional context, will hopefully prove applicable to other arenas and contexts of design and may well open the door for further investigation of design as a lived and experienced process. Using the metaphor of language in practice, we can begin to understand the nonlinear, collective, and dynamic character of fashion design. All of this asks us to seriously reconsider our myth of the romantic artist working in solitude to execute masterpieces with grace and fluidity. Though these students' final designs display an enviable level of mastery, skill, and imagination, their success is also attributable to the intensive work required to conceptualize and execute such designs. When asked what they felt the public would be surprised to know about the design process, two of the interviewees referred to the extreme amount of hard work that went into both the thought process and the design process. Understanding the process that led to the final product allows us to gain an understanding of this hard work and gives us a new appreciation for the object, which is never simply an object. Understanding the practice of design is therefore crucial to our understanding of the theory of design; using this knowledge can help us understand the collective power both designers and their garments have for expressing ideas about culture and society and asking us, as members of that society, to do the same.

\section{References}

Becker, H. S. (2008). Art worlds (2nd ed.). Berkeley, CA: University of California Press. Bourdieu, P. (1993). The field of cultural production: Essays on art and literature. R. Johnson (Ed.). New York, NY: Columbia University Press. Chafe, W., ed. (1980). Preface to Volume III. In The pear stories: Cognitive, cultural, and linguistic aspects of narrative production. Norwood, NJ: Ablex. Cholachatpinyo, A., Padgett, I., Crocker, M., \& Fletcher, B. (2002a). A conceptual model of the fashion process - Part 1: The fashion transformation process model. Journal of Fashion Marketing and Management, 6, 11-23. Cholachatpinyo, A., Padgett, I., Crocker, M., \& Fletcher, B. (2002b). A conceptual model of the fashion process - Part 2: An empirical investigation of the micro-subjective 
level. Journal of Fashion Marketing and Management, 6, 24-34. Weinstein, J. I. (2009). The market in Plato's Republic. Classical Philology, 104, 439-58. Ingold, T. \& E. Hallam. (2008). Creativity and cultural improvisation: An introduction. In T. Ingold \& H. Hallam (Eds.), Creativity and Cultural Improvisation (pp. 1-24). Paris: Berg. Keane, W. (2003). Semiotics and the social analysis of material things. Language \& Communication, 23, 409425. Kuspit, D.B. (1993). The Cult of the avant-garde artist. Cambridge: Cambridge University Press. Liddicoat, A.J. (2007). An introduction to conversation analysis. London; New York, NY: Continuum. McRobbie, A. (1998). British fashion design: Rag trade or image industry? London; New York, NY: Routledge. MFA design student (1), personal communication, October 27, 2010. MFA design student (2), personal communication, November 4, 2010. MFA design student (3), personal communication, November 4, 2010. Ono, T., \& Thompson, S.A. (1995). What can conversation tell us about syntax? In P. W. Davis (Ed.), Alternative Linguistics: Descriptive and Theoretical Modes (213-271). Amsterdam: John Benjamins. Parsons The New School for Design. (2010). Fashion Design and Society (MFA) Curriculum. Accessed October 18, 2010.

http://www.newschool.edu/parsons/mfa-fashion-designsociety-curriculum/ Salzmann, Z. (1998). Introducing linguistic anthropology. In Language, Culture, and Society: An Introduction to Linguistic Anthropology (pp. 1-26). Boulder, CO: Westview Press. Singerman, H. (1999). Art subjects: Making artists in the American university. Berkeley, CA; Los Angeles, CA: University of California Press. Thornton, S. (2009). Seven days in the art world. New York, NY: W.W. Norton \& Co.

\section{Resumen:}

¿Cómo interactúan, alimentándose unos a otros, los impulsos creativos y las experiencias vividas en el desarrollo del proceso de diseño? Este proyecto examina la mecánica del proceso creativo mediante la observación de la obra de tres estudiantes graduados de diseño de moda, como un primer paso hacia la comprensión de la naturaleza del proceso de diseño y la simbiosis entre el objeto y el proceso, utilizando ideas tomadas de la teoría lingüística moderna como punto de partida para la investigación. Tomando como referencia a Cholachatpino et al. (2002) y su categorización micro-subjetiva del proceso de la moda como "un proceso dinámico y no un continuo lineal", junto con Ingold y de Hallam (2009) y su noción de improvisación cultural y teorías relacionadas desde el campo de la antropología lingüística, este artículo sostiene que el proceso de diseño de moda está abierto a la clase de improvisación inherente a cualquier experiencia que se vive; y el producto final representa la culminación de las ideas, deseos, decisiones, obstáculos y otras circunstancias que determinan su producción. Las ideas no se traducen en su forma material de una manera fluida y sin complicaciones; de hecho, hay muchas formas intermedias de la interrupción, la desviación, la reformulación, y la rearticulación, no muy diferentes de nuestro uso cotidiano del lenguaje en la conversación. Reconsiderar el proceso de diseño con una mirada hacia la explicación de su colectivo, no lineal, y la naturaleza experimental nos permite reconocer que el diseño tiene el potencial para informarnos sobre la sociedad y darnos las herramientas para producir cambios en ella.

Palabras clave:

creatividad - improvisación cultural - proceso de diseño - diseño de moda - lenguaje.

Resumo: 
Como interagem, alimentando-se uns a outros, os impulsos criativos e as experiências vividas no desenvolvimento do processo de design? Este projeto examina a mecânica do processo criativo mediante a observação da obra de três estudantes graduados em design de moda, como um primeiro passo até a compreensão da natureza do processo de design e a simbiose entre o objeto e o processo, utilizando idéias tomadas da teoria lingüística moderna como ponto de partida para a pesquisa. Tomando como referencia a Cholachatpino et al. (2002) e sua categorização micro- subjetiva do processo da moda como um processo dinâmico e não um contínuo lineal, junto com Ingold e Hallam (2009) e sua noção de improvisação cultural e teorias relacionadas desde o campo da antropologia lingüística, este artigo sustenta que o processo de design de moda está aberto à classe de improvisação inerente a qualquer experiência que se vive; e o produto final representa a culminação das idéias, desejos, decisões, obstáculos e outras circunstancias que determinam sua produção. As idéias não se traduzem em sua forma material de uma maneira fluida e sem complicações; de fato, há muitas formas intermédias da interrupção, o desvio, a re-formulação e a re-articulação, não muito diferentes de nosso uso cotidiano da linguagem na conversa. Reconsiderar o processo de design com uma mirada até a explicação do seu coletivo, não lineal, e a natureza experimental permite reconhecer que o design tem o potencial para informar-nos sobre a sociedade e dar-nos as ferramentas para produzir câmbios nela.

Palavras chave:

criatividade - improvisação cultural - processo de design - design de moda - linguagem.

Fashion as practice, fashion as process: using principles of language as a framework for understanding the design process fue publicado de la página 225 a página238 en Cuadernos del Centro de Estudios de Diseño y Comunicación N N 64 